\title{
Scanning Electron Microscopic Studies on Rabbit's Spinal Cord by Resin Cracking Method
}

\author{
Kenji Oнtsuki
}

Received March 23, 1972

Summary. Small pieces cut from the spinal cord of the rabbit were fixed and dehydrated and embedded in gelatin capsules filled with Cemedine 1500. The Cemedine was hardened at $-30^{\circ} \mathrm{C}$ and the capsules were cracked into two pieces. The cracked surface of the specimen was observed under the scanning electron microscope.

1. In the cytoplasm of the anterior horn cell the Nissl bodies were observed like specks. The Nissl bodies were denser than the cytoplasm surrounding them and contained numerous granules (about $400 \AA$ in diameter) and membranous structures oriented parallel to each other. In the cytoplasm corresponding to the Golgi regions many vesicles and cisternal and membranous structures could be seen. On the surface of nerve cell bodies small swollen terminations of axons, which seemed to be end-bulbs, were observed.

2. The membranes consisting of myelin sheaths, which surrounded the axon as a whirlpool, were observed in three dimensions. The myelin sheath sometimes extended thinner processes which could be considered to be the cytoplasmic processes of the neuroglial cell.

3. The cilia covering the ependymal cells of the central canal were fairly uniform in number (12-15) from cell to cell, and were arranged in a tuft for each cell. The surface was also rich in microvilli which formed various shapes.

The usefulness of the scanning electron microscope in revealing fine details of the surface morphology of cells and tissues has been already established. Recently, scanning electron microscopic studies of nervous tissue have been reported on the chick spinal cord (Boyde et al., 1968), cilia in the brain (DALEN et al., 1971), isolated neurons (HAMBERGER et al., 1970), and isolated nerve fibers (SPENCER and LiEBERMAN, 1971). However, all of these studies have treated with the surface morphology of cells and tissues, and there have been no studies performed on the inner structure as far as is known.

In the present study on the anterior horn cells, the neuroglia cells and the myelinated nerve fibers of the spinal cord as observed with the scanning electron microscope, the author attempted not only to reveal the surface morphology of cells and tissues but also their interior structure, making use of TANAKA's resin cracking method.

\section{Materials and Methods}

Adult rabbits weighing $2.5-3.5 \mathrm{~kg}$ were used. Under ether anesthesia the rabbits were perfused via the abdominal aorta with $300 \mathrm{ml}$ of warmed physiological saline and then with $500 \mathrm{ml}$ of $2.5 \%$ glutaraldehyde buffered with phosphate $(\mathrm{pH}$ 7.4). After the perfusion, the spinal cord was removed and specimens (about $7 \times 2 \times$ $2 \mathrm{~mm}$ ) were dissected out. The specimens were fixed in $5 \%$ glutaraldehyde buffered with phosphate (pH 7.4) for $2 \mathrm{hrs}$ at room temperature, and subsequently postfixed in 
$1 \%$ osmium tetroxide buffered with veronal-acetate ( $\mathrm{pH} 7.4$ ) for 3 hrs at $4^{\circ} \mathrm{C}$, dehydrated in graded ethanol, and immersed in propylene oxide for $15 \mathrm{~min}$. The resin cracking method (TANAKA, 1972) was then applied. In this method the specimens were embedded in No. 2 capsules filled with Cemedine 1500 (epoxy resin). The Cemedine in the capsules was hardened in a cryostat at $-30^{\circ} \mathrm{C}$. After sufficient hardening of the Cemedine, the capsules were cracked with a chisel and hammer. The broken pieces of capsules were put into propylene oxide to remove the Cemedine from the specimens. Subsequently the specimens were transferred to amyl acetate, and then dried by the critical point drying method (ANDERSON, 1951). Some specimens were dried by the acetone drying method. After drying, carbon and gold were applied to the cracked surfaces of the specimens in a vacuum evaporator and the material was examined under a Hitachi HSM-2 scanning electron microscope.

\section{Observations}

Nerve cells

The anterior horn cells of the spinal cord were chosen as the subject of observation. The motor cells of the anterior horn were extremely large neurons, and the cell bodies were generally pyramidal or polygonal in shape. They had a large, round nucleus located in the center of the cell body. The most conspicuous object in the nucleus of the nerve cell was the nucleolus, which was an extremely dense mass clearly demarcated from the rest of the karyoplasm (Fig. 1). On the surface of the nerve cell bodies small swollen terminations of axons, which seemed to be

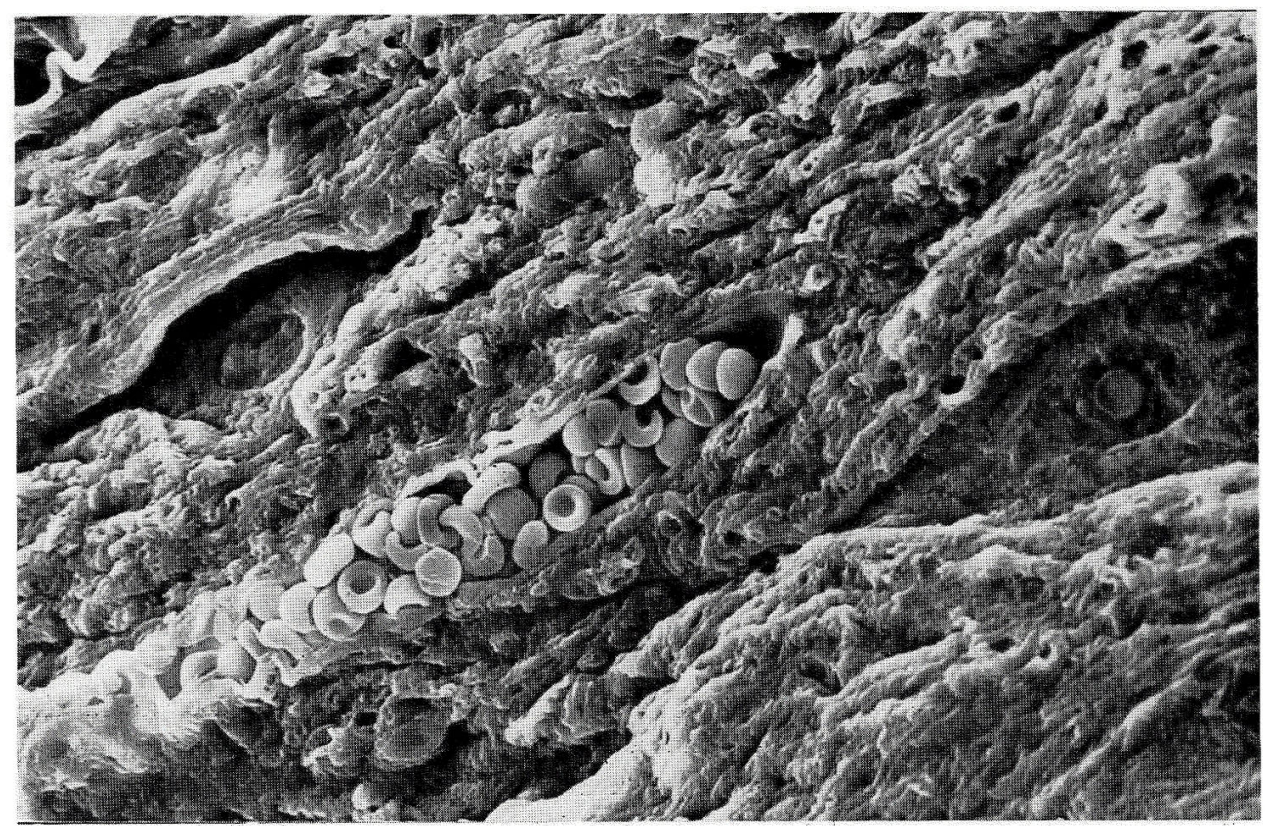

Fig. 1. A scanning electron micrograph showing the anterior horn of the spinal cord. Two nerve cells, which have a large cell body and round nucleus with a conspicuous nucleolus, and a blood vessel are seen. $\times 1.300$ 


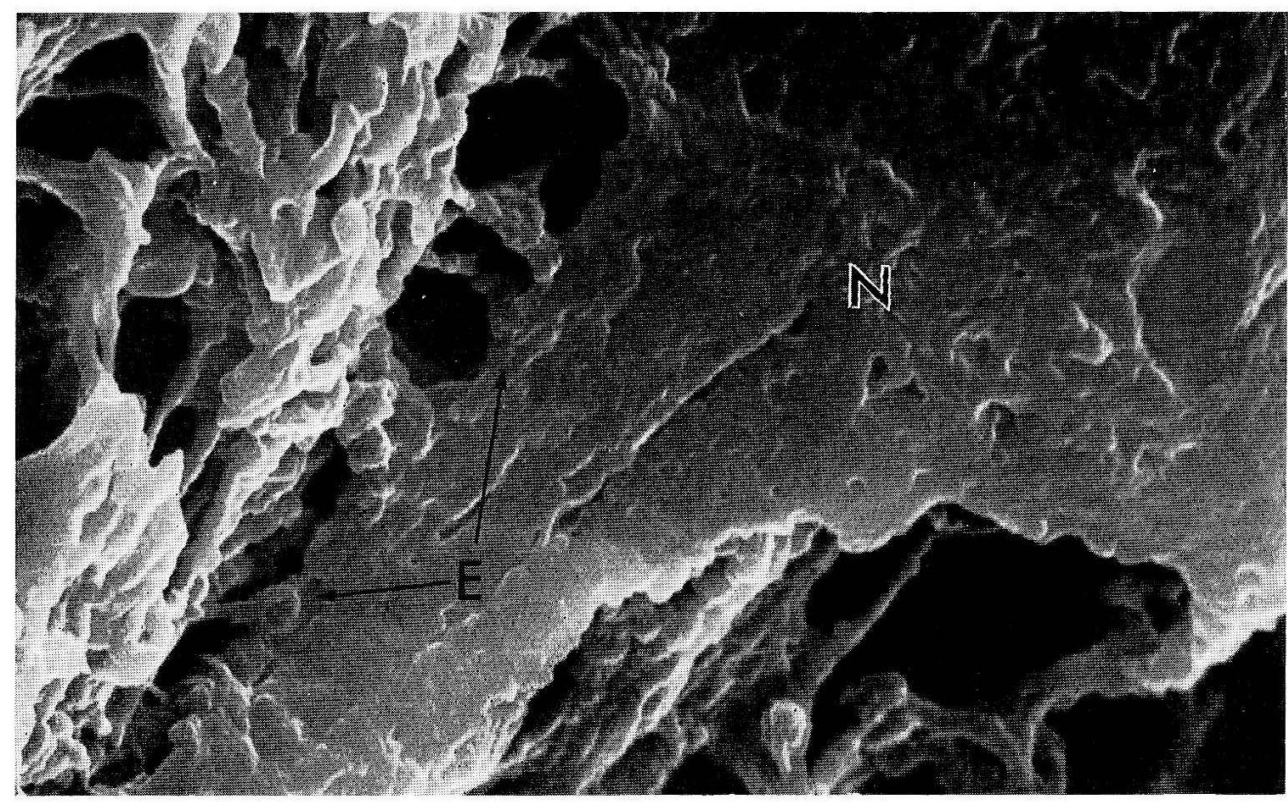

Fig. 2. A scanning electron micrograph showing end-bulbs $(E)$ which are attached to the surface of a nerve cell $(N) . \quad \times 5,000$

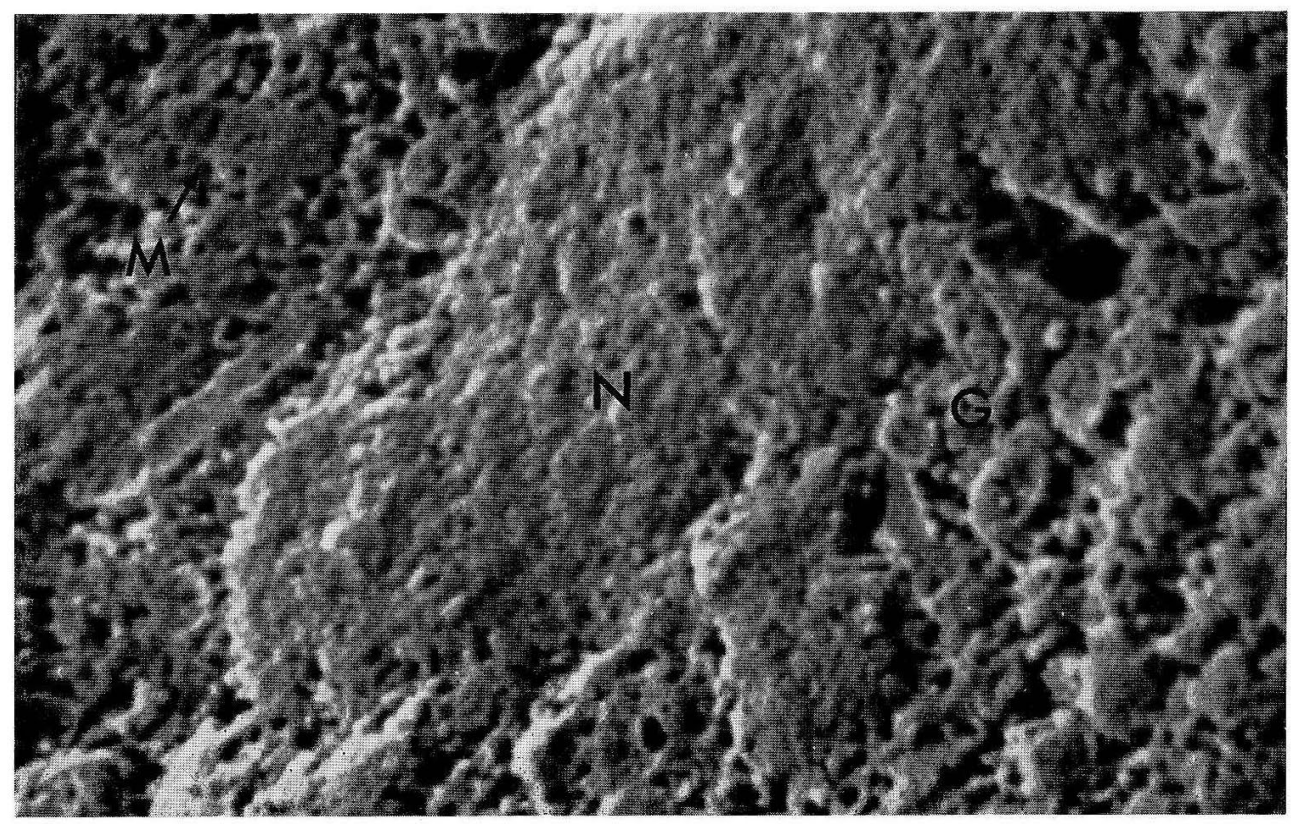

Fig. 3. Cytoplasm of an anterior horn cell. Nissl bodies $(N)$, Golgi complex $(G)$ and mitochondria $(M)$ are observed. $\times 20,000$ 
end-bulbs, could often be seen (Fig. 2). These were mainly observed in the specimens which were considerably shrunk due to the dehydration procedure (acetone drying method).

In the cytoplasm of the anterior horn cells, large clumps were observed, similar to those that were visible with the aid of the light microscope. These clumps were identified with what are generally termed Nissl bodies. The Nissl bodies were denser in architecture than the cytoplasm surrounding them and they contained many granules. These granules were about $400 \AA$ in diamctcr and supposed to be concerned with ribosomes. Also membranous structures were observed in lines in the Nissl bodies which were thought to be the rough-surfaced endoplasmic reticulum.

On the other hand, in the cytoplasm around the Nissl bodies, especially close to the nucleus, there existed many vesicles and cisternal membranous structures. These were thought to be the Golgi complex. The mitochondria were generally disposed in the cytoplasm between the Nissl bodies, and the cristae mitochondriales were identified on their cracked surface (Fig. 3).

\section{Myelinated nerve fibers}

The white matter of the spinal cord consisted of myelinated nerve fibers supported by the neuroglial cells which lay between the myelinated nerve fibers.

Under the scanning electron microscope it was clearly seen that cylindric myelinated nerve fiber bundles ran up and down the cord. On the cross section of the nerve fibers, the axon and the myelin sheath could be clearly differentiated

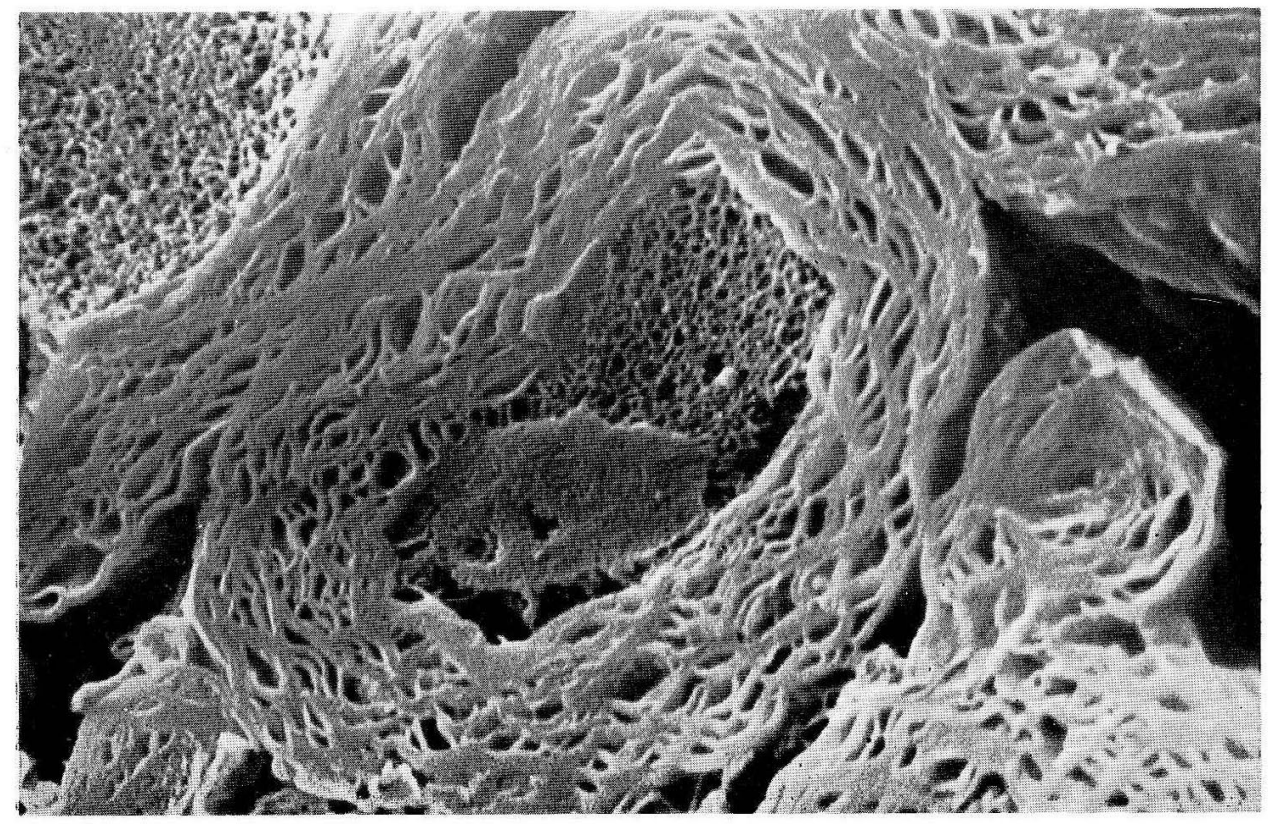

Fig. 4. A scanning electron micrograph showing a cross section of myelinated nerve fibers. Myelin sheaths surround the axon like a whirlpool. $\quad \times 8,800$ 


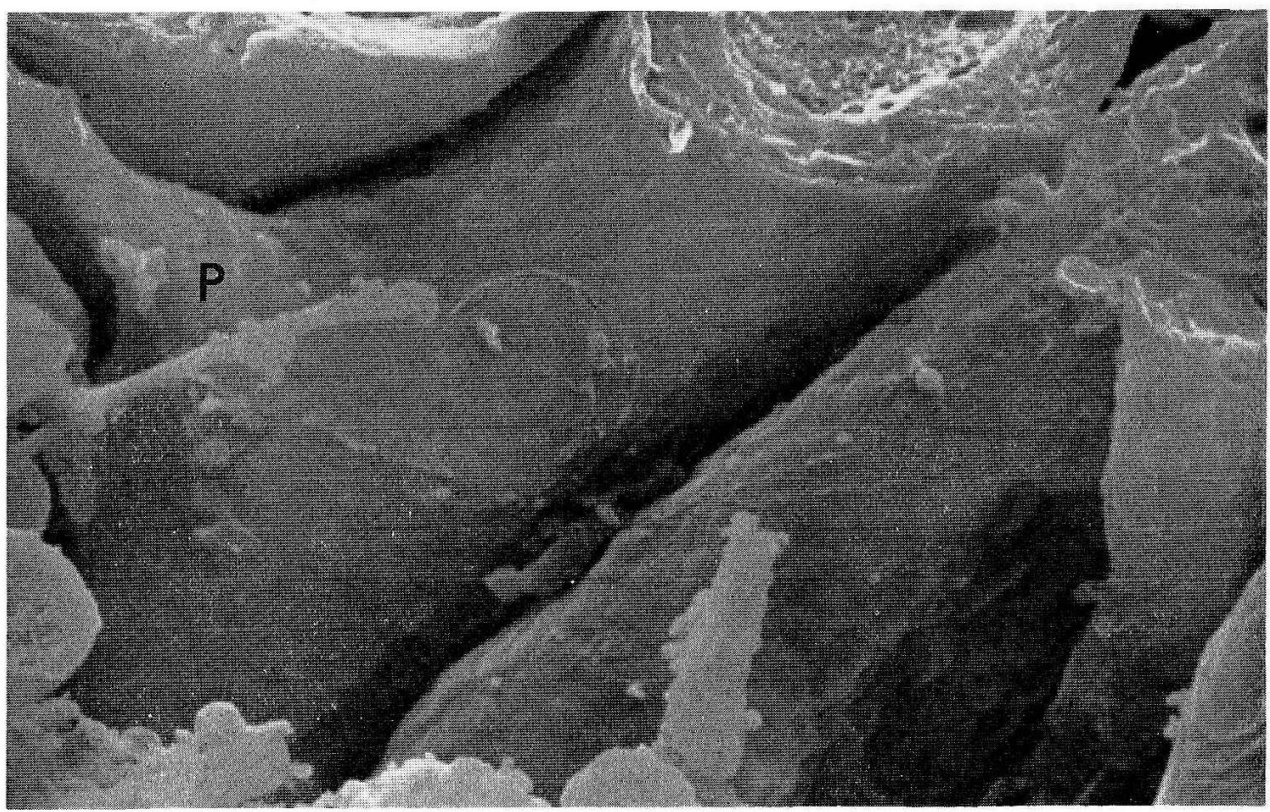

Fig. 5. Surface of myelinated nerve fibers. A branching process $(P)$ and some fibrils are seen. $\times 4,600$

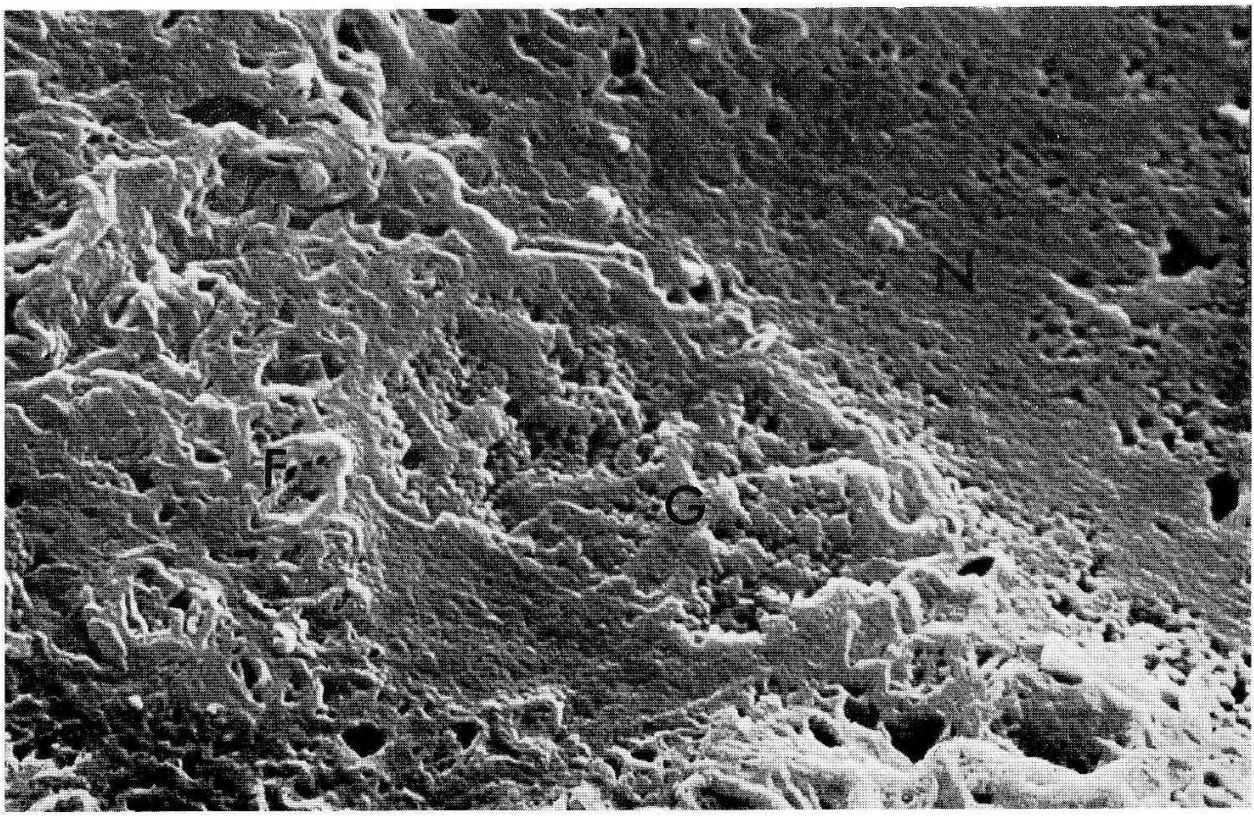

Fig. 6. A neuroglial cell $(G)$ in the gray matter. It exists close to a nerve cell $(N)$ and has groups myelinated nerve fibers $(F)$ around it. $\times 8,500$ 
under the scanning electron microscope. The myelin sheath consisted of membranes which surrounded the axon in a whirl and generally looked wavy. The axon appeared like a sponge and was surrounded by the axolemma. Sometimes objects which were supposed to be mitochondria could be seen in the axon (Fig. 4). The fibrils which seemed to be fine collagen fibers could be seen on the outerlayer of the myelin sheaths. Occasionally the myelin extended a thin branch which was assumed to be derived from the cell body of a neuroglial cell (Fig. 5).

\section{Neuroglial cells}

Some neuroglial cells were observed in the gray matter. Frequently were seen satellite cells in close association with the nerve cells. The cell bodies were round or oval in shape and far smaller than those of the nerve cells. They had many processes and were also often associated with groups of myelinated nerve fibers (Fig. 6). In the white matter, cells with a large round nucleus and comparatively rich cytoplasm occurred in rows between the myelinated nerve fibers (Fig. 7).

\section{Ependymal cells}

The ependymal cells around the central canal of the spinal cord consisted of a sheet of epithelial cells. Many cilia and numerous microvilli covered the free surface of the ependymal cells and there seemed to be no difference in the number of cilia from cell to cell. Some 12-15 cilia which built up a tuft on the ependymal cell were derived from the center of the cell surface. Such tufts resembled young rice plants in the paddyfield (Fig. 8). The cilia were about $15 \mu$ in length and $0.6 \mu$ in diameter.



Fig. 7. A neuroglia cell in white matter exists between myelinated nerve fibers $(F)$ and has a round nucleus. $\times 7,000$ 
They were smooth surfaced and terminated in a rounded tip. The microvilli were far shorter than the cilia in length and formed various shapes; their tip was expanded like a drumstick. The microvilli were thickly grown around the center of the cell surface in the same manner as the cilia, but were scarcely seen at the periphery of the cell surface (Fig. 9).

\section{Discussion}

A distinguishing feature of the motor nerve cells of the spinal cord is the large number of Nissl bodies, which under the transmission electron microscope are seen to be rough-surfaced endoplasmic reticulum and free ribosomes (PALAY and PALADE, 1955). The cell bodies of motor neurons are readily identified by their large size, characteristic nucleus and cytoplasm, and synaptic apparatus (BoDIAN, 1964).

According to the present observation, the parts of the cytoplasm which correspond to the Nissl bodies are denser than the cytoplasm surrounding them. They contain many granules about $400 \AA$ in diameter. The granules are presumed to correspond to the ribosomes (TANAKA, 1972), and the linear structures observed in the Nissl bodies may be equivalent to the rough-surfaced endoplasmic reticulum. The vesicles, cisterns and membranous structures near the nucleus can be regarded as the Golgi complex. Mitochondria and their cristae are clearly identified under the scanning electron microscope, though the two membranes of the mitochondria, outer and inner, are not clear. On the other hand, no neurofilaments and neurotubles could be identified.

Secondly, as for the myelinated nerve fibers under the scanning electron microscope, myelin sheaths are observed in three dimensions consisting of numerous



Fig. 8. Free surface of the central canal. Cilia are uniform in distribution and number from cell to cell. Tufts of cilia are oriented in a particular direction and numerous microvilli are seen. $\quad \times 1,800$ 


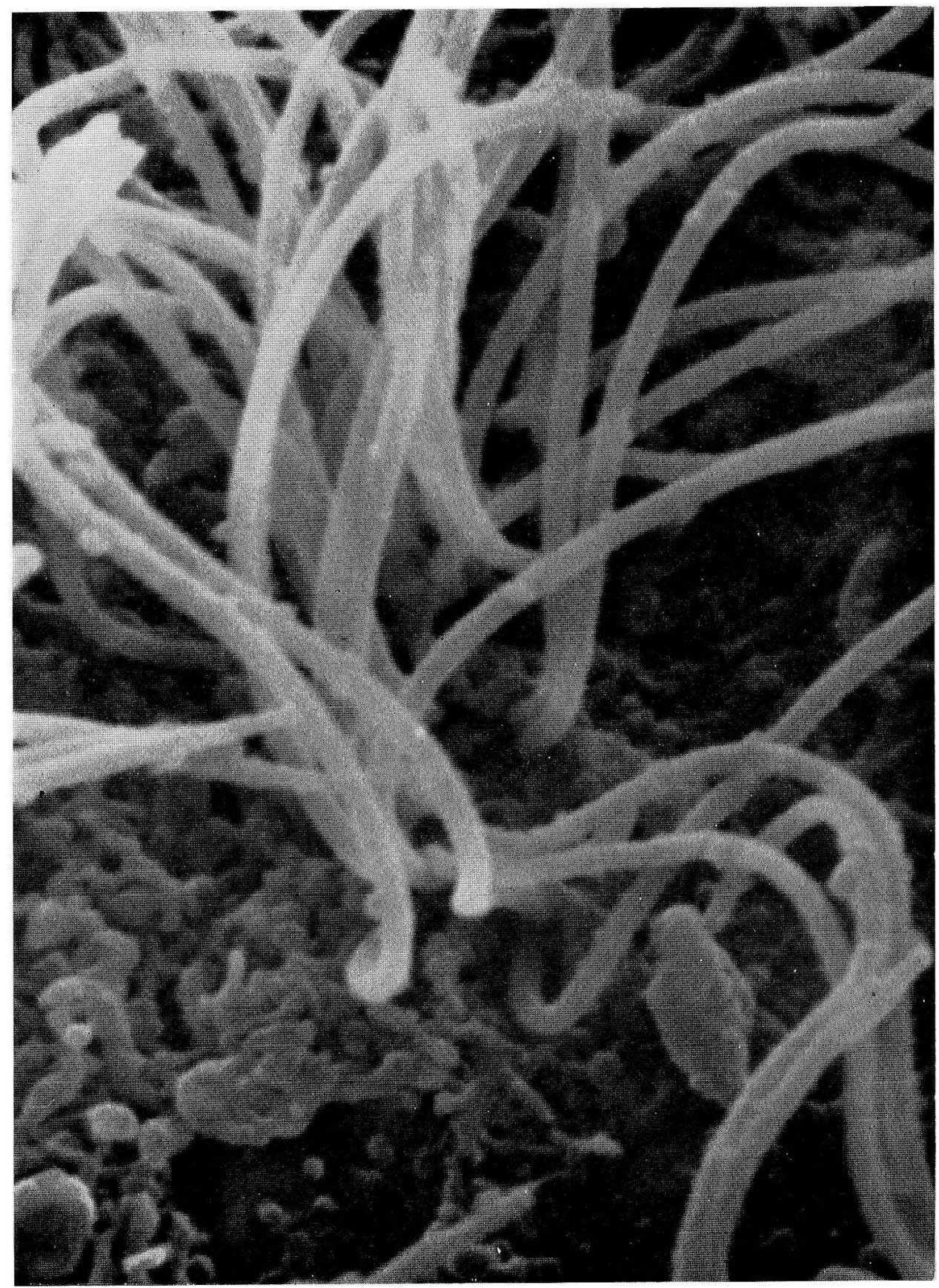

Fig. 9. A scanning electron micrograph showing the cilia of the central canal. They number 12-15 for each cell. $\times 18,000$ 
membranes surrounding the axon as a whirl. Generally, when the membranes appear wavy, they are to be considered as artificial products caused by drying. The appearance of fibrils which are supposed to be collagen fibers lying on the external sheath of the axon resembles that of fibrils in the schematic diagram of a myelinated nerve fiber by MoRan (1953). The myelin sheaths are also observed to extend branching processes which, according to the present observation, often can be followed to the cell body of a glial cell. Bunge et al. (1961) have reported that several sheaths may be connected to one glial cell by processes. The processes in question are thus believed to be the cytoplasmic processes of glial cells which connect the glial cells and the myelin sheaths.

Finally neuroglial cells are dealt with. On the basis of light microscopic investigations, the neuroglial cells of the central nervous system are generally classified into four kinds, astrocytes, oligodendrocytes, microglia and ependymal cells. However, the identification of different neuroglial cells in transmission electron microscope preparations is not always easy except for ependymal cell.

By scanning electron microscopy, it is also impossidle to make exact identification of the different neuroglial cells, though the ependymal cells are readily identified because they are arranged around the central canal of the spinal cord and provided with cilia and microvilli.

As for the ependymal tissue in the ventricle of the brain, comprehensive studies by transmission electron microscopy have been performed by BRIGHTMAN and PALAY (1963), and Kohno and Usui (1966). They have reported that there is a great difference in distribution and number of cilia from cell to cell, and numerous projections are found which are too irregular in their dimensions to be termed microvilli.

With regard to the ependymal cells of the central canal, Schultz et al. (1956) have observed that their free surface has two types of processes, a bulbous cytoplasmic expansion with many fingerlike microvilli and true and typical cilia. Both processes may be found on the same ependymal cell.

The present scanning electron micrographs demonstrate the cilia of the ependymal cells life-like in three dimensions.

With regard to the ciliary activity, it has been recognized up to date that the direction of the ciliary motion in the brain corresponds to the movement of the cerebrospinal fluid. The rapid sweeping strokes seem to be coordinated in a particular direction, and are thought to be important for the circulation of the cerebrospinal fluid in the brain (Worthington and CATHCART, 1963; DALEN et al., 1971). The cilia of the central canal may be considered to have the same motions as the cilia in the brain. In the present observation, the cilia in the central canal are fixed in a particular direction, but it is not clear from this finding whether there is a correlation between the ciliary movements and the circulation of the cerebrospinal fluid in the central canal.

Acknowledgement. Grateful acknowledgement is made to Prof. Kéiichi Tanaka for his constant guidance, and to Mr. Y. KAshima and Mr. H. Osatake for their assistance in this study. 


\title{
樹脂割断法によるウサギ脊髉の走査電子顕微鏡的観察
}

\author{
大月 健 二
}

長方形の細片としてとり出した奉髄の材料を固定，脱水し，セメダイン 1500 をみたし

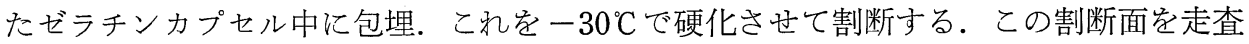
電子鏡で観察して次の結果を得た。

1. 前角細胞では，光学顕微鏡で見られるようにニッスル小体が斑点状に認められる。 この部分は周囲の細胞質にくらべて緻密で, 中には直径 $300-600 \AA ̊$ の顆粒が無数に含ま れ，また膜状構造が平行に走るのが見られた。一方 ゴルジ野に相当する部位には 小胞 および槽状の膜構造物の存在が観察された。 また 細胞体表面には シナプス終末とおも われる附着体が見られた。

2. 有髄神経線維では 透過電子顕微鏡で見られるような 髄鞘および軸索が観察され た。また 神経線維から枝が出ているのが認められた。これは 神経膠細胞の細胞質突起 であろう。

3. 中心管の自由表面には線毛と微絨毛があり, 前者は 10 数本が 1 束となって 1 個の 上衣細胞表面中央に位置し, あたかも田植後の稲苗のように中心管内に突出して, 一定 の方向になびいている，また 後者は太鼓揆状で 細胞表面中央部に無数に存在する.

\section{References}

Anderson, T. F.: Techniques for the preservation of threedimensional structure in preparing specimens for the electron microscope. Trans. N. Y. Acad. Sci. 13: 130-134 (1951).

Bodian, D.: An electron microscopic study of the monkey spinal cord. Bull. Johns Hopkins Hosp. 114: 13-119 (1964).

Boyde, A., D. W. James, R. L. Tresman and R. A. Willis: Outgrowth from chick embryo spinal cord in vitro, studied with the scanning electron microscope. Z. Zellforsch. 90: 1-18 (1968).

Brightman, M. W. and S. L. Palay: The fine structure of ependyma in the brain of the rat. J. Cell Biol. 19: 415-439 (1963).

Bunge, R. P., M. B. Bunge and H. Ris: Ultrastructural study of remyelination in an experimental lesion in adult cat spinal cord. J. biophys. biochem. Cytol. 10: 67-94 (1961).

Dalen, H., W. T. Schlapfer and A. Mamoon: Cilia on cultured ependymal cells examined by scanning electron microscopy. Exp. Cell Res. 67: 375-379 (1971).

Hamberger, A., H. A. Hansson and J. Sjöstrand: Surface structure of isolated neurons. Detachment of nerve terminals during axon regeneration. J. Cell Biol. 47: 319-331 (1970).

Kohno, K. and T. Usui: Electron microscopic studies on ependymal cilia and their basal feet on the ventral stalk of the rat subfornical organ. Bull. Tokyo Med. Dent. Univ. 13: 381-405 (1966).

Fernandez-Moran, H.: Sheath and axon structures in the internode portion of vertebrate mylinated nerve fibers. An electron microscope study of rat and frog sciatic nerves. Exp. Cell Res. 1: 309-340 (1950).

Palay, S. L. and G. E. Palade: The fine structure of neurons. J. biophys. biochem. Cytol. 1: 6988 (1955). 
Schultz, R., E. C. Berkowitz and D. C. Pease: The electron microscopy of the lamprey spinal cord. J. Morphol. 98: 251-273 (1956).

Spencer, P. S. and A. R. Lieberman: Scanning electron microscopy of isolated peripheral nerve fibers. Normal surface structure and alterations proximal to neuromas. Z. Zellforsch. 119: 534-551 (1971).

Tanaka, K.: Freezed resin cracking method for scanning electron microscopy of biological materials. Naturwiss. 59: 77 (1972).

Worthington, W. C., Jr. and R. S. Cathcart, III.: Ependymal cilia: Distribution and activity in the adult human brain. Science 139: 221-222 (1963).

\author{
大月健二 \\ 宁683 米子市西町 \\ 鳥取大学医学部 \\ 第二解剖学教室
}

Dr. Kenji Oнтsuki

Department of Anatomy

Tottori University School of Medicine

Yonago, 683 Japan 